\title{
Understanding of subsurface conditions controlling flow liquefaction occurrence during the 2018 Palu earthquake based on resistivity profiles
}

\author{
Adrin Tohari ${ }^{1 *}$, Dadan Dani Wardhana ${ }^{1}$, Muhammad Hanif $^{1}$, and Keigo Koizumi ${ }^{2}$ \\ ${ }^{1}$ Research Center for Geotechnology, National Research and Innovation Agency (BRIN), Bandung, West Java, Indonesia 40135 \\ ${ }^{2}$ Graduate School of Engineering, Division of Global Architecture, Osaka University, Osaka, Japan 565-0871
}

\begin{abstract}
The $7.4 \mathrm{Mw}$ earthquake on $28^{\text {th }}$ September 2018 in Palu City triggered a flow liquefaction phenomenon in the Balaroa and Petobo areas, contributing to significant casualties and building damage. This paper presents the results of a liquefaction study to map subsurface conditions in these areas using the multielectrode resistivity method with the dipole-dipole configuration. The objective of this study is to understand factors controlling the flow liquefaction phenomenon. Based on the interpretation of 2-D resistivity images, the liquefied soil layers are characterized by lower resistivity values than the non-liquified layers. These contrasts of resistivity values form a gently sloping boundary between the liquefied and non-liquefied soil layers. The resistivity image perpendicular to the flow direction indicates the presence of a subsurface basinal morphology in the Balaroa area, suggesting that a shallow groundwater zone is present within the liquefiable soil layer. Thus, the subsurface topographical condition is the main governing factor of flow liquefaction phenomena during the 2018 Palu earthquake.
\end{abstract}

\section{Introduction}

The earthquake (7.4 Mw) that occurred in Palu City, Sigi, and Donggala Regencies on 28 September 2018 caused not only a tsunami but also a flow liquefaction phenomenon in several areas in Palu City and Sigi Regency. The occurrence of flow liquefaction resulted in significant casualties and extensive damage to residential areas and infrastructures in the Balaroa and Petobo areas in Palu City and Sigi Binomaru, Jono Oge, and the South Sibalaya areas in Sigi Regency (Fig. 1).

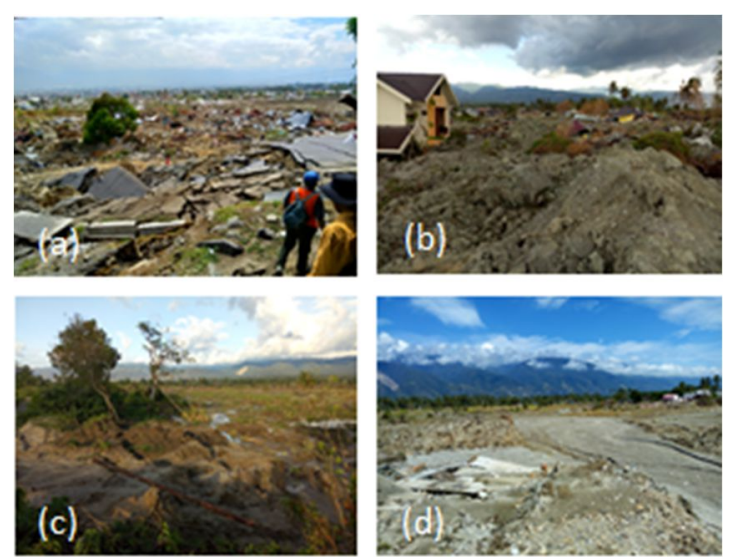

Fig. 1. Flow liquefaction phenomena in (a) Balaroa, (b) Petobo, (c) Ojo Oge and (d) South Sibalaya.

\footnotetext{
* Corresponding author: adrin.tohari@gmail.com
}

Flow liquefaction failure generally occurs in areas with a slope of more than $5 \%[1,2]$ and is caused by the presence of a thin layer of sand beneath the dense soil layer [2]. As mentioned previously, the phenomenon of flow liquefaction in Palu City and Sigi Regency only occurred in some areas (see Fig. 1). This difference in liquefaction vulnerability is likely influenced by geological, hydrological, and subsurface soil structure conditions that vary from one region to another. Thus, it is essential to have good knowledge and understanding of the factors of geological conditions and subsurface structures that control flow liquefaction in Palu City and Sigi. Such knowledge is required to establish an effective strategical plan to mitigate this earthquake-collateral hazard in this region.

The understanding of liquefaction occurrences is commonly gained from field geotechnical investigations such as geotechnical drilling with standard penetration tests and cone penetration tests. Although these geotechnical methods provide detailed sub-surface data required for liquefaction analysis, such as soil types, groundwater level, and soil strength, these methods are costly and time-consuming.

Many previous studies have recently attempted to use geophysical methods, such as resistivity survey, to understand the subsurface condition in liquefaction-prone areas [3-5]. Based on the resistivity images, [3] established a correlation of resistivity values with liquefiable soil layers and liquefaction controlling 
fractures in San Carlo, Italy, due to the 20 May 2012 earthquake $(\mathrm{Ml}=5.9)$. [4] found a good correlation of the thickness and depth of liquefiable soil layers determined from the resistivity image and the CPT data. [5] concluded that the liquefaction phenomenon in the Pawnee area due to the 2016 Pawnee, Oklahoma earthquake (Mw 5.8) is associated with the presence of isolated lenses of conductive sediments and subsurface fractures formed by the earthquake. The resistivity method has also been used to study the flow liquefaction phenomenon in Balaroa and Petobo areas after the 2018 Palu earthquake [6, 7]. However, the studies only focused on the identification of a shallow aquifer that controlled the liquefaction phenomenon. Thus, no previous studies have been attempted to evaluate subsurface factors controlling a flow liquefication phenomena.

This paper presents the results of a liquefaction study to evaluate subsurface conditions controlling flow liquefaction phenomenon in Balaroa and Petobo areas using the multi-electrode resistivity method. The objectives of this study are to (1) obtain the 2-D resistivity images and (2) evaluate the subsurface factors governing the flow liquefaction in Balaroa and Petobo.

\section{Geology of Palu City}

According to [8], Palu City is made up of two rock formations, namely alluvial and coastal deposits (Qap) and Celebes Molasse (QTms). The alluvial and coastal deposits consist of gravel, sand, silt, and coral limestone and are the youngest sediments in this area. The deposits were formed in rivers, deltas, and shallow seas and are likely Holocene in age.

The alluvial deposits can be differentiated into young and old alluvial fan deposits, alluvial, flood, and old river channel deposits [9]. The alluvial fan deposits are found on the hilly low plains that stretch on the west and east sides of the valley.

The Celebes Molasses are found at lower altitudes on both ridges, unconformably overlapping the Tinombo Formation $(\mathrm{Tt})$ and metamorphic rock complex $(\mathrm{km})$ [8]. The molasses contain debris originating from older formations and consists of conglomerates, sandstones, mudstones, coral limestones, and marls, which are weakly consolidated. Near the metamorphic rock complex in the western part of the eastern ridge, the molasse deposits consist mainly of coarse boulders and are presumably deposited near the fault. Toward the sea, the rocks turn into fine-grained clastic rocks.

The main fault controlling geological structure in the Palu City area is the well-known Palu-Koro Fault, an active fault with left-lateral movement and an NNW-SSE trend [10-14]. The strike-slip fault is observable within the basin, crosses the distal part of alluvial fans, and is expressed by intra-basin ridges in slightly uplifted places from the adjacent surface [15]. The 7.5 Mw earthquake in 2018 revealed the main Palu-Koro fault line in the ground surface. The surface fault line can be traced from Sigi Regency, Palu City, and Palu Bay [14, 16]. The maximum slip of the Palu-Koro fault is $6 \pm 0.5 \mathrm{~m}$ around Palu City, with an average of up to $4.7 \mathrm{~m}$ in the northern and southern areas of the City [17].

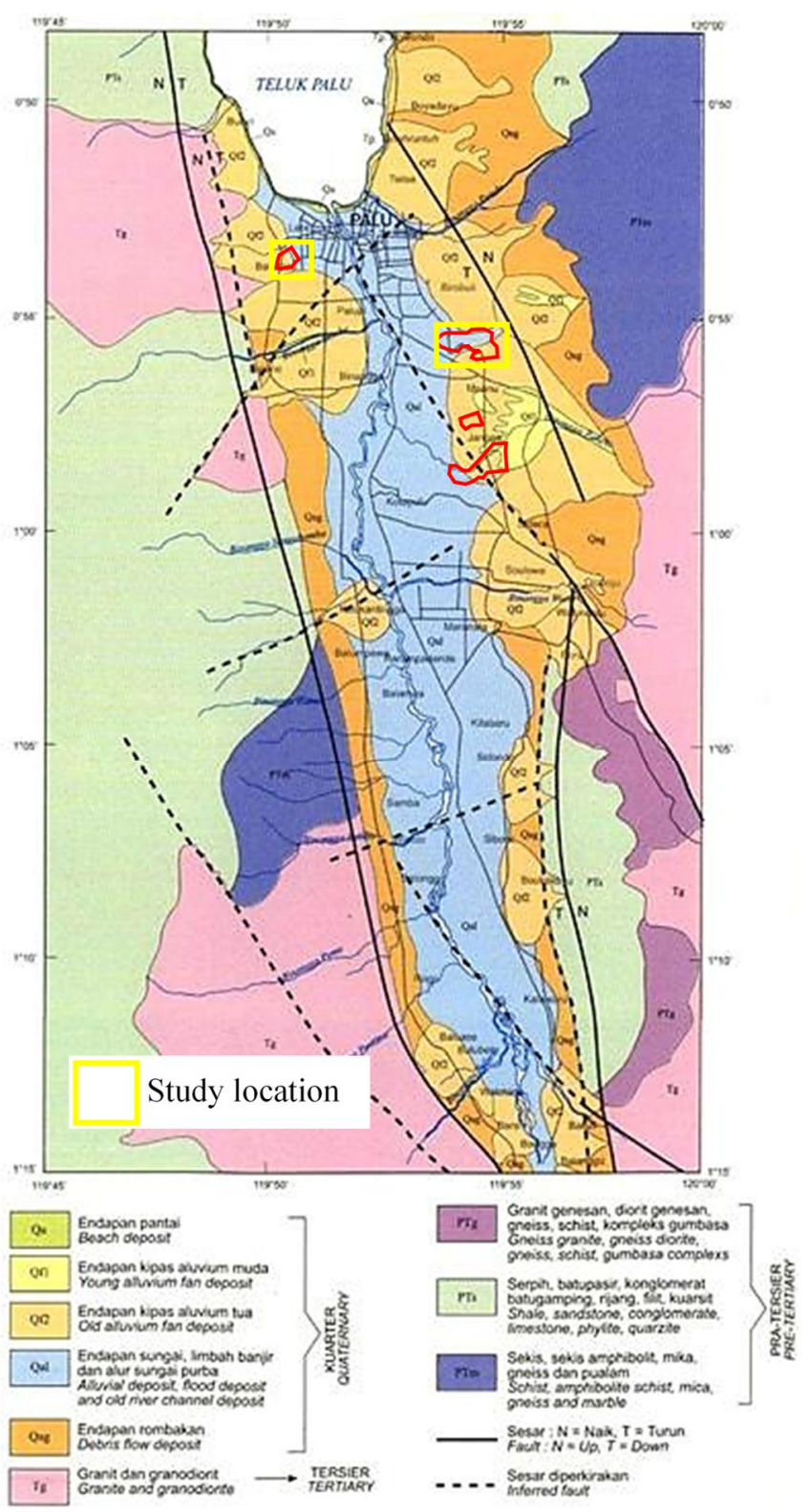

Fig. 2. Geological map of Palu City and its surrounding area [9]

\section{Methodology}

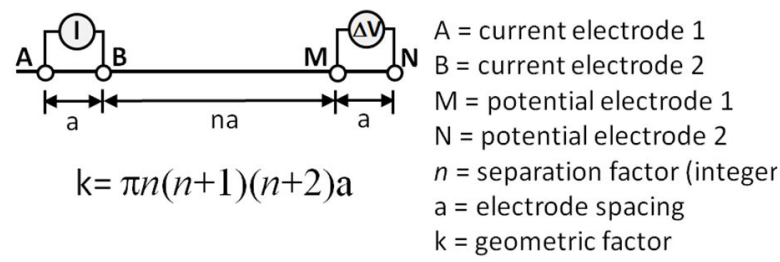

Fig. 3. Electrode arrangement for resistivity array of dipoledipole.

Geoelectric measurements were carried out at flow liquefaction locations in the Balaroa and Petobo areas using Supersting R8/IP equipment to obtain twodimensional resistivity profiles up to a depth of $70 \mathrm{~m}$. The 
equipment was connected to 56 stainless steel electrodes, laid out in a straight line at equal distances apart using a multi-core cable. The dipole-dipole array was used for data protocol acquisition in providing comprehensive data resolutions (Fig. 3). Two survey lines crossing

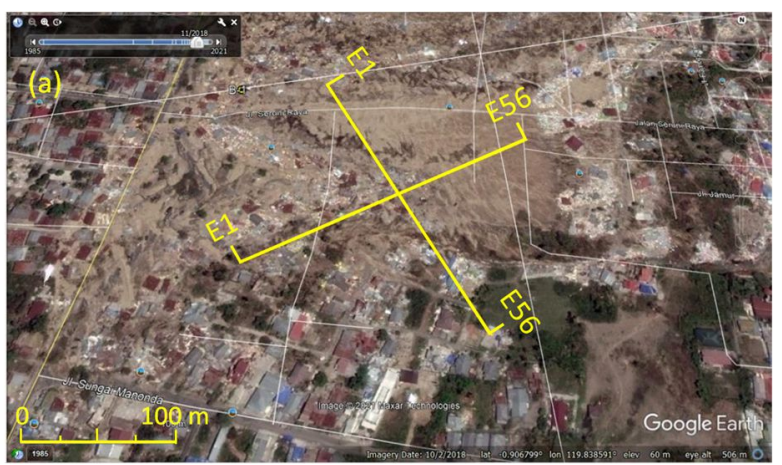

perpendicular to one another were selected at the Balaroa site. Only one line was selected at Petobo (Fig. 4). The length and direction of each line are summarized in Table 1. The elevation of each electrode was measured using GPS.

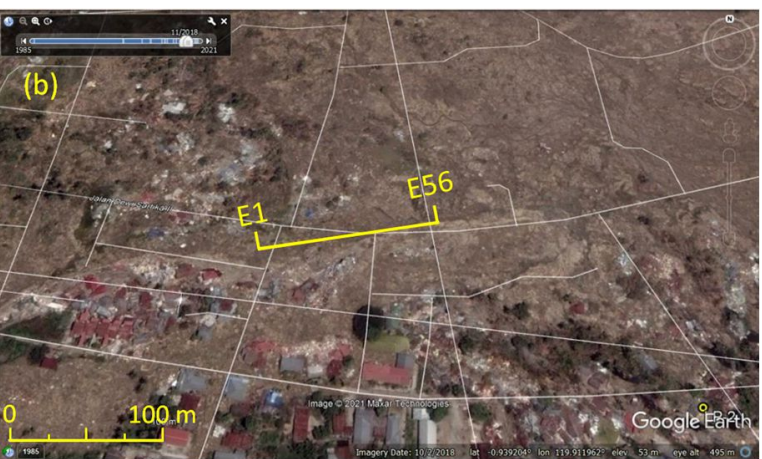

Fig. 4. Map of resistivity survey location showing the survey lines (yellow lines) in (a) Balaroa and (b) Petobo sites. The images of google earth were taken in January 2019. Notation E1 and E56 indicates the locations of the first and the last electrodes,respectively.

The measurement data were edited using AGI Administrator software. Then, inverse modeling was performed using AGI Earth Imager to obtain subsurface resistivity profiles.

Table 1. Resistivity survey locations.

\begin{tabular}{|l|c|c|c|c|}
\hline \multirow{2}{*}{$\begin{array}{c}\text { Locatio } \\
\mathbf{n}\end{array}$} & \multicolumn{2}{|c|}{ Coordinate (50M) } & \multirow{2}{*}{$\begin{array}{c}\text { Spacing } \\
(\mathbf{m})\end{array}$} & $\begin{array}{c}\text { Length } \\
(\mathbf{m})\end{array}$ \\
\cline { 2 - 3 } & $\mathbf{X}(\mathbf{m E})$ & $\mathbf{Y ~ ( m S )}$ & & 275 \\
\hline Balaroa & 816281.80 & 9899604.43 & 5.0 & 275 \\
\hline Balaroa & 816281.80 & 9899604.43 & 5.0 & 275 \\
\hline Petobo & 824241.00 & 9895970.00 & 2.5 & 140 \\
\hline
\end{tabular}

\section{Results and discussions}

\subsection{Resistivity profiles in the Balaroa site}

Fig. 5 and 6 present the two-dimensional resistivity profiles for the Balaroa site in WSW-NNE and NNW-SSE directions, respectively. The resistivity values for the Balaroa site range from $25-105 \Omega \mathrm{m}$ with depth coverage of about $70 \mathrm{~m}$. The resistivity profiles show that the soil layers near the surface have low resistivity values of less than $50 \Omega \mathrm{m}$, which is likely to be associated with alluvial deposits. Meanwhile, the underlying high resistivity layers are probably associated with the old alluvial fan deposit.

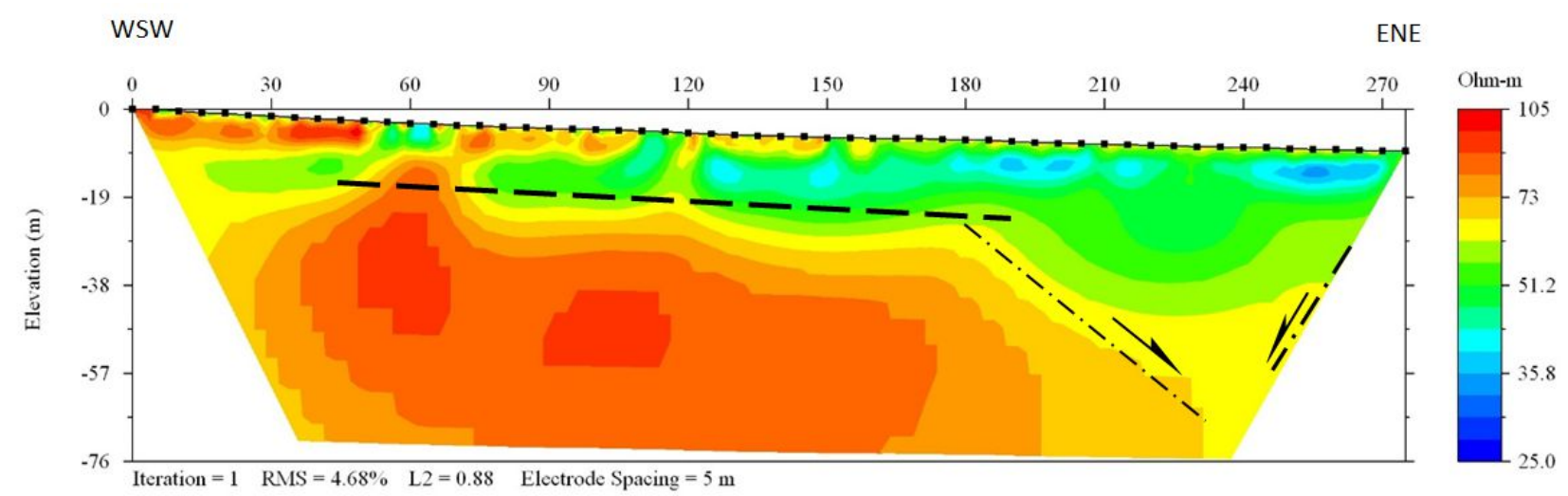

Fig. 5. Resistivity profile for WSW-ENE direction at the Balaroa site. The black dotted line indicates the inclined plane at the boundary between the soil layer with low resistivity and the soil/rock layer with high resistivity. Dashed-doted lines and arrows indicate the normal faulting. The profile map view is shown on Fig. 4 a.

As shown in Fig. 5, the boundary between alluvial deposits and the old alluvial fan layer forms an inclined plane at a very gentle angle from west to east. Thus, this subsurface topography is likely to govern the initiation of movement of liquefied soil mass to turn into flow liquefaction during the earthquake. Fig. 5 also indicates the thickening of alluvial deposits to the east due to the existence of a basinal structure associated with the normal faulting component of the Palu-Koro Fault. [18] also found this basin geometry from the analysis of microtremor measurement data in this area.

Meanwhile, Fig. 6 indicates that the boundary between low and high resistivity seems to form a basin geometry associated with normal faulting components of the PaluKoro Fault. This basin geometry will control groundwater flow to this liquefied area. Consequently, shallow 
groundwater levels will easily develop in this area to cause the soil mass to liquefy during the earthquake. The old alluvial fan deposits seem to disappear, and the alluvial deposits become thicker in the southeast direction. Consequently, this area experienced less intense flow liquefaction than the main area during the earthquake, as evidenced in Fig. 4(a).

Furthermore, the examination of Fig. 5 and 6 clearly shows that the boundaries between alluvial deposits and alluvial fan deposits are still intact after the flow liquefaction event. It implies that the flow liquefaction only involved the alluvial deposits. The presence of high

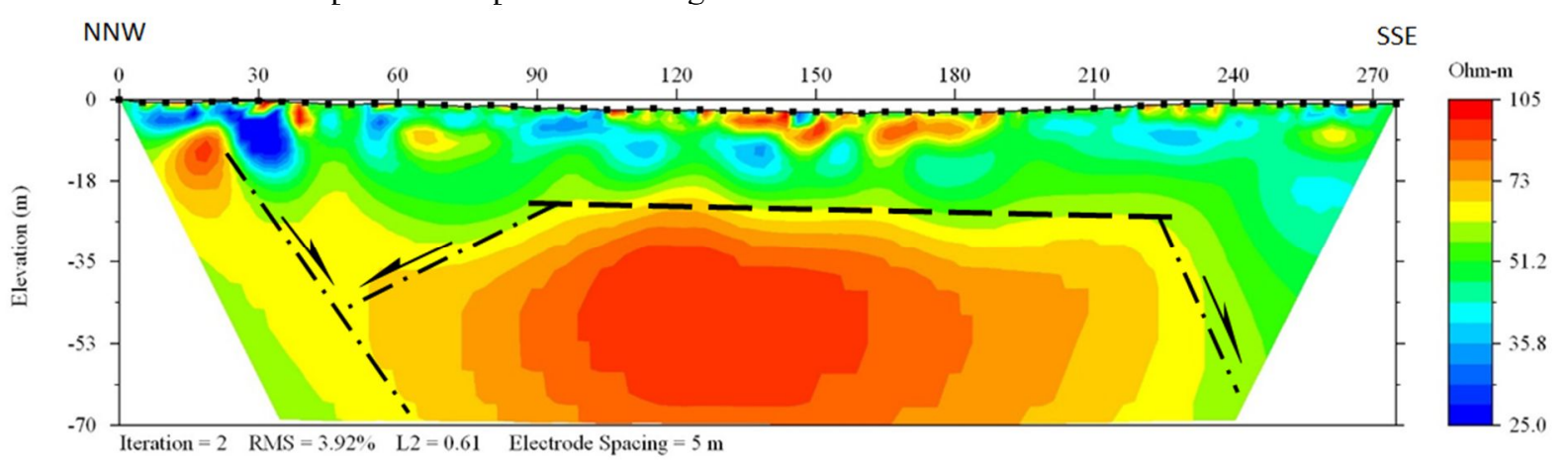

Fig. 6. Resistivity profile for NNW-SSE direction at the Balaroa site. The black dotted line indicates the inclined plane at the boundary between the soil layer with low resistivity and the soil/rock layer with high resistivity. Dashed-doted lines and arrows indicate the normal faulting. The profile map view is shown on Fig. 4a.

\subsection{Resistivity profiles in the Petobo site}

Fig. 7 presents the results of the geoelectric survey for the east-west direction at the flow liquefaction location in the Petobo area. The resistivity profile shows that the resistivity values range between 2 and $200 \Omega$ mith a coverage depth of $36 \mathrm{~m}$. The soil layer with a low resistivity profile (less than $40 \Omega \mathrm{m}$ ) is probably associated with the alluvial deposits. In contrast, the high resistivity layers $(>40 \Omega \mathrm{m})$ are probably associated with the old alluvial fan deposits. Some fragments of alluvial fan deposits can also be found near the surface, as indicated by higher resistivity values, in most parts of the slope profile. The boundary between these different deposits forms an inclined plane at a gentle angle from east to west that controls the generation of flow liquefaction. Close resistivity layers at the ground surface is associated with the remnants of alluvial fan deposits being displaced during the earthquake.

It is also evident that the alluvial deposits indicated by low resistivity of less than $30 \Omega \mathrm{m}$ at a depth of shallower than $10 \mathrm{~m}$ were locally developed after the liquefaction event. This finding suggests that the highly saturated soil layers are still present within the liquefied soils. Hence, the area is still prone to a liquefaction hazard in the future. examination of Fig 5 and 7 suggests that the inclined boundary in the Petobo site is steeper than in the Balaroa site. Consequently, the liquefied soils in the former flowed at a greater distance than in the latter.

Fig. 7 also shows the presence of basinal structures within the alluvial fan deposits, probably due to normal faulting associated with the movement of the Palu-Koro Fault. This basin geometry may control groundwater accumulation within the alluvial deposits, which leads this sediment mass to be highly saturated, and thus, highly liquefiable during the earthquake. Localized very low resistivity layers are still detected within the alluvial deposits, indicating saturated alluvial deposits are still present near the ground surface in the upper part of the slope profile. These pieces of evidence indicate that the Petobo liquefied area is still prone to flow liquefaction in the presence of a strong earthquake in the future.

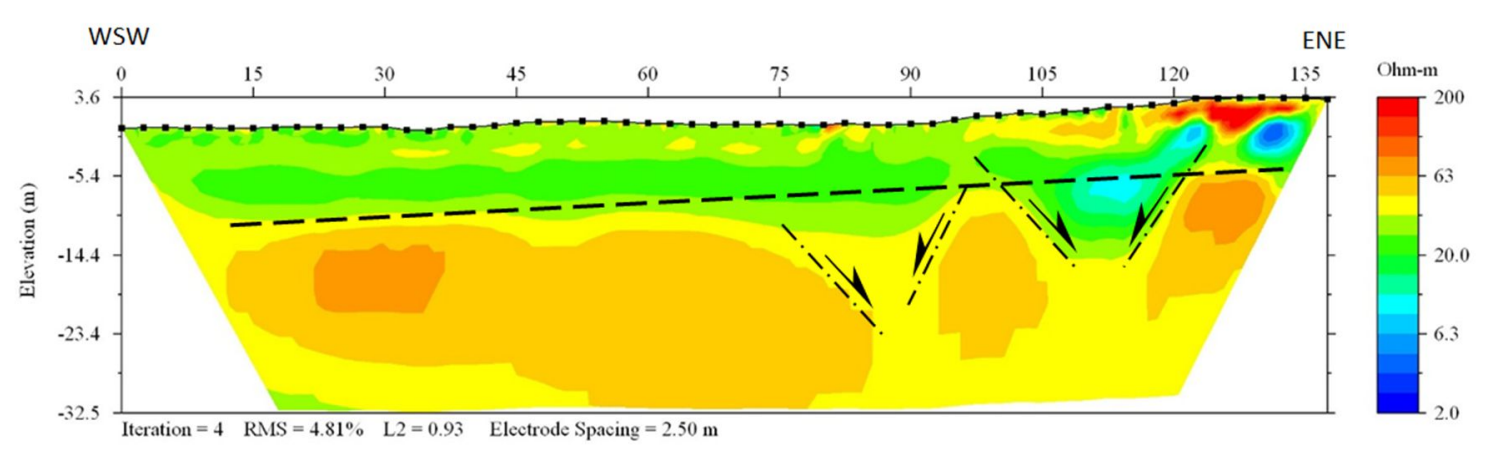

Fig. 7. Resistivity profile for WSW-ENE direction at the Petobo site. The black dotted line indicates the inclined plane at the boundary between the soil layer with low resistivity and the soil/rock layer with high resistivity. Dashed-doted lines and arrows indicate the normal faulting. The profile map view is shown on Fig. $4 \mathrm{~b}$. 


\subsection{The implication to flow liquefaction hazard risk assessment}

The result of this current study indicates the critical role of local sub-surface topography as a governing factor for flow liquefaction. Even though thick loose sediments with shallow groundwater exist in most areas of Palu City, massive flow liquefaction only occurred in Balaroa and Petobo areas. In other words, the subsurface topographical condition in other areas with a gentle hillslope in Palu city is not favorable for flow liquefaction. Thus, this study signifies the importance of a comprehensive subsurface geological investigation, using a combination of geotechnical and geophysical methods to map sedimentary basin geometry for the potential flow liquefaction risk assessment in other cities prone to intense earthquake shaking. A massive flow liquefaction event, like in Balaroa and Petobo, may also occur in other coastal cities built on a sedimentary basin.

\section{Conclusions}

Based on the results of the geoelectric survey, the following conclusions can be drawn:

(a) Low resistivity sediment layers associated with alluvial deposits are mostly present above the higher resistivity sediments of alluvial fan deposits.

(b) The subsurface topographic features, such as a gently inclined boundary between the liquefiable soil and the underlying alluvial fan deposits and basin morphology associated with normal faulting of the Palu-Koro Fault, are the governing factors of the flow liquefaction phenomenon in the Balaroa and Petobo areas.

(c) The occurrence of flow liquefaction in Balaroa and Petobo signify the importance of a comprehensive subsurface geological study to assess the flow liquefaction risk in other earthquake-prone coastal cities.

This study was funded by the 2019 INSINAS research grant of the Ministry of Research, Technology, and Higher Education of the Republic of Indonesia.

\section{References}

1. T.L. Youd, Civil Eng. 48, 4, 47 (1978)

2. T.L. Youd, Geologic effects-liquefaction and associated ground failure, in Proceedings of the Geologic and Hydrologic Hazards Training Program, 5-30 March 1984, Denver, Colorado (1984)

3. N.A Zeid, S. Bignardi, R. Caputo, G. Santarato, M. Stefani, Annals of Geophys. 55, 4, 713 (2012)
4. M. Jinguuji, S. Toprak, Exploration Geophys. 48, 28 (2017)

5. F. Kolawole, E.A. Atekwana, A. Ismail, Earthquake Seis. Res. Lett. 88, 1017 (2017)

6. A. Arsyad, L. Samang, T. Harianto, A.B. Muhiddin, A.R. Djamaluddin, S. Aswad, Reconstructing mechanism of large ground movement induced by 2018 Palu Earthquake 7.4 Mw, in Proceedings of the $7^{\text {th }}$ International Conference on Earthquake Geotechnical Engineering, 17-20 June 2019, Rome, Italy (2019)

7. S. Nurdin, T. Harianto, S. Aswad, A. Arsyad, S. Alexsander, Liquefaction disaster mitigation and geohydrology conditions, lessons from the Palu earthquake magnitude 7.4 Mw 28, in Proceeding of the $23^{\text {rd }}$ Annual National Conference on Geotechnical Engineering, 12-13 November 2019, Jakarta, Indonesia (2019)

8. H. Sumadirdja, T. Suptandar, S. Hardjoprawiro, D. Sudana, Reconnaissance geological map of the Palu quadrangle, Sulawesi, Geological Research and Development Center Geologi, Bandung (1973)

9. A. Soehaimi, M. Firdaus., I. Effendi, Earthquake susceptibility zonation map of Palu and its surrounding area. Geological Research and Development Center, Bandung (2000) in Indonesian

10. J.A. Katili, Geol Rundsch. 59, 581 (1970)

11. H.D. Tjia, Bull. Geol. Soc. Malaysia 10, 73 (1978)

12. O. Bellier, M. Sébrier, D. Seward, T. Beaudouin, M. Villeneuve, E. Putranto, Tectonophys. 413, 201 (2006)

13. M.R. Daryono, Paleoseismologi Tropis Indonesia (With Case Studies of the Sumatran Fault, the Palu Koro-Matano Fault, and the Lembang Fault). Dissertation Doctoral Program. Institut Teknologi Bandung (2016). Unpublished

14. I.M. Watkinson, R. Hall, Fault systems of the eastern Indonesian triple junction: evaluation of Quaternary activity and implications for seismic hazards Geohazards in Indonesia in Earth Science for Disaster Risk Reduction. editor / P. Cummins; I. Meilano, Geol. Soc. London 441, 71 (2017)

15. A. Patria, P. S. Putra, Geosci. Lett. 7, 1 (2020)

16. A.I. Abdullah, Abdullah J. Phys.: Conference Series, 1434, 012009 (2020)

17. H. Bao, J.P. Ampuero, L. Meng, E.J. Fiedling, C. Liang, C.W.D. Milliner, T. Feng, H. Huang, Nat. Geosci. 12, 200 (2019)

18. A. Cipta, A. Rudyanto, H. Afif, R. Robiana, A. Solikhin, A. Omang, Supartoyo, S.Hidayati, Geol. Soc., London, Special Publications, 501, 185 (2020) 